Article

\title{
Toward Sustainable and Inclusive Housing: Underpinning Housing Policy as Design for Values
}

\author{
Marja Elsinga ${ }^{1}$, Joris Hoekstra ${ }^{1}$, Mohamad Sedighi ${ }^{1, *(1)}$ and Behnam Taebi ${ }^{2}(\mathbb{C}$ \\ 1 Faculty of Architecture and the Built Environment, Delft University of Technology, \\ 2628 BX Delft, The Netherlands; m.g.elsinga@tudelft.nl (M.E.); j.s.c.m.hoekstra@tudelft.nl (J.H.) \\ 2 Faculty of Technology, Policy and Management, Delft University of Technology, \\ 2628 BX Delft, The Netherlands; B.Taebi@tudelft.nl \\ * Correspondence: S.M.A.Sedighi@tudelft.nl
}

Received: 24 January 2020; Accepted: 23 February 2020; Published: 3 March 2020

\begin{abstract}
A perusal of the literature on housing debates reveals that the term 'value' is mostly applied to express the financial value of a house and is dealt with in economic literature. However, an alternative meaning of the word 'value' in the housing literature can be found in research into the values underlying housing preferences, applying research methods from the marketing literature. The explicit combination of moral values and housing policy and design is found neither in the academic housing nor in the philosophical literature. However, diving deeper into the housing debate reveals that there are a host of moral values already present throughout this debate that are often not explicitly articulated and explicated, such as inclusiveness, sustainability, autonomy, and security. The aim of this paper is to address the role of values in housing policy and design. By doing so, we apply the Design for Values approach (DfV). We argue that the DfV approach can help to make implicit moral values more explicit, which can improve the housing debate, housing policy-making, and housing design. The paper first explores which values are relevant for housing policy and design and operationalizes those values. Next, the paper describes key debates in housing such as: What is "adequate housing" in times of rapid urbanization and increasing house prices? We argue that by exploring the underlying values of these debates, stakeholders can create a better understanding of the current (lack of) fundamental discussions on housing issues
\end{abstract}

Keywords: housing policy; design for values (DfV); inclusiveness; sustainable community

\section{Introduction}

In this paper, we propose a Design for Values (DfV) approach for understanding the role that moral values can play in housing design and housing policy. The first aim of this paper is to understand how these values have featured in housing decisions, policies, and debates. The second, at least equally important, aim of the paper is to provide a framework that could help to proactively make informative value-driven decisions in housing. This is consistent with the Design for Values (DfV) approach in the literature on the ethics of technology. The paper aims to extend this approach into the realm of housing.

In his seminal book 'Freedom to Build', John Turner provided two definitions for the notion of housing: 'housing' as a verb indicates action and events that refer to the act of community-making, while 'housing' as a noun connotes an object, a static phenomenon that is equal to the result of the production of houses [1]. By distinguishing between these definitions, Turner's aim was to emphasize the importance of housing for community-making and planning. In this paper, both of Turner's definitions are relevant, depending on the type of value that we look at. So, in our discussions about 'design for values in housing', we explicitly intend to include two aspects: (1) the design of a house (or series of houses) as an object and (2) housing as community-making. In doing so, we pay 
ample attention to the housing policies that are developed to facilitate and enhance the two aspects mentioned above.

The paper is organized as follows. In Section 2, we explain the Design for Values approach, expounding on the Value Hierarchy notion, and introducing the concepts 'norms' and 'design requirements'; this section will further consider the alternative approach of Multi-Criteria Decision-Making (MCDM), arguing that the DfV approach offers a unique and invaluable lens for the analysis of housing issues. Section 3 will further the discussion on the relevance of values in housing. Section 4 presents a tentative list of values, but it also includes norms that could matter in decision and policy-making in housing. Section 5 presents debates in housing design and policy and aims to link these debates to values, norms, and design requirements. Section 6 reflects on the meaning of our paper to the current debates on housing and outlines what the perspective of design for values can contribute.

\section{The Design for Values Approach}

The DfV approach should be considered as an extension of the Value-Sensitive Design (VSD) approach that has been primarily introduced in information technology and for designing human computer interaction $[2,3]$, but has later been elaborated to address the inclusion of moral values in other domains of technological design [4-8].

VSD originates from information technology and from the acknowledgement that there are important ethical values, such as user autonomy or freedom from bias, that are being designed into computer systems; if the designer does not appropriately include them during the design, it might prove difficult, or even impossible, to include them after the design has been completed. In the words of an important pioneer of VSD, Batya Friedman, we should create "computer technologies that-from an ethical position-we can and want to live with" [9] (p. 17). VSD for the first time systematically reviews these values at an early stage through an iterative tripartite methodology consisting of conceptual, empirical, and technical investigations [10].

Conceptual investigations aim at conceptually (that is, not yet empirically) identifying the direct and indirect stakeholders, the values at stake, their potential conflicts, and the inevitable value trade-offs. By contrast, empirical investigations aim at answering the conceptual questions by investigating them among the stakeholders, particularly focusing on how values are perceived and how choices were made when two values are in conflict. For example: "How do stakeholders apprehend individual values in the interactive context? How do they prioritize competing values in design trade-offs? How do they prioritize individual values and usability considerations? Are there differences between espoused practice (what people say) and actual practice (what people really do)?" [10]. The technical investigations focus on the suitability of a certain technology for accommodating certain values.

The Design for Values (DfV) approach rests on the assumption that an "explicit and transparent articulation of values" is highly relevant to design and innovation and it will allow for designing for shared values [11] (p. 3). The tools, methodologies, and procedures in DfV have been mostly developed in relation to the literature on the ethics of technology. The DfV approach further rests on three main claims, as expressed and spelled out in a seminal Handbook of Ethics, Values and Technological Design: i.e., (i) values can be expressed and embedded in technology; (ii) it is ethically relevant to explicitly think about these values; and iii) for the values to have a serious bearing on design and development, they should come at an early stage [8]. Applying this to building houses, in principle, these claims do not only relate to designing a building (a dwelling) but also to the broader questions of housing policy. Let us briefly review how they relate to the design of buildings but also to housing policies.

One could argue that values shape or constrain the space of action for future users of technology. For instance, designing a building with inclusiveness as a leading value means that there should not be stairs and other physical hurdles for a disabled person. This claim is sometimes discussed by referring to a famous quote of Winston Churchill, “We shape our buildings and afterwards our buildings shape 
us", which dates back to 1943 and the rebuilding of the destructed Chamber of the Parliament. The original plan was to follow a horseshoe design, as favored by many other parliaments [12]. However, Churchill objected to this and successfully argued for the "adversarial rectangular pattern" that better reflected the essence of the two-party system of British parliamentary democracy. Values, as embedded in design choices (Claim 1), embody important ethical features of design (Claim 2). Since many choices are made from the outset and at the design table, they cannot be unmade afterwards (Claim 3); that is, a horseshoe design cannot be simply 'adjusted' to a rectangular design. Indeed, this example shows the relevance of early stage acknowledgement and the inclusion of values in the design of buildings. In a similar vein, we argue that values also play an important role in housing policies and the makeup and use of cities, urban areas, and dwellings. To illustrate this with an example, in the 1970s, so-called drive-in dwellings were relatively popular in the Netherlands. Drive-in dwellings are single-family dwellings with a garage on the ground floor, next to the main entrance. The living and sleeping spaces are mainly positioned on the upper floors. This reflects the importance of the automobile (related to the value autonomy) in those days. Nowadays, the automobile occupies a less important position in the life of most people; this is partially because it less reflects the value of autonomy. Consequently, drive-in dwellings are hardly built anymore. Moreover, in the existing drive-in dwellings, most of the garages are used as a storage area or a working space rather than as a place to park the car.

Before moving on to discuss more elaborately why values are relevant in housing policies in the next section, let us first briefly present a working definition of moral values and discuss how they are different to market values and public values. As a working definition, we assume that values are things that are worth striving for moral reasons, or "what a person or group of people consider important in life" [13] (p. 349). Therefore, values are different from individual preferences, wishes, and desires, in that they relate to a common good that we wish to uphold for everyone. To say that something is valuable means not only that it is valuable to me, but also that "it is or should be of value to others" [5] (p. 974). Not all preferences and choices are explicitly linked with and expressed in conjunction with such values. Our focus is on preferences and choices that are motivated and stem from profound beliefs about stakeholders' conception of what is considered to be good, which is expressed in terms of values. Value statements in engineering design indicate whether "certain things or state-of-affairs are good, valuable, or bad in a certain respect" [5] (p. 974). Then, according to this definition, accessibility is to be considered a value, because we could assume that accessibility is relevant for moral reasons, and it represents not a personal preference but a commonly shared morally relevant characteristic.

The moral values that we discuss in this paper are also somewhat different from "the "public value" concept as discussed in the literature on policy sciences [14]. Whereas public values are closely related to the functioning of the public administration, the moral values that we have defined have a more comprehensive scope. They are also different from "market values". The literature on values extensively discusses the matter of how market relates to morality, distinguishing views from market libertarians defending that "a proper functioning of market institutions will, just by itself, ensure morally acceptable outcomes" to moral critiques of the market [15] (p. 1). More broadly, the relationship between ethics and economics is often debated [16]. While some of the values that we identify and further discuss in this paper have an explicit or implicit economic component in them (e.g., market efficiency), our notion of values aims to encompass a broader meaning of morally relevant features of housing.

While values are often general notions at a rather high level of abstraction, engineering design is often based on more concrete guidelines and instructions. Therefore, values must first be translated into design requirements. This process is also called value specification or operationalization. For a further specification of values in design, we will follow the notion of a Value Hierarchyas introduced by Van de Poel as a "hierarchy structure of values, norms and design requirements" [17] (p. 235) A Value Hierarchyis depicted as a triangle divided in three levels. The top level consists of values and the bottom level includes the design requirements that pertain to "certain properties, attributes or capabilities that the designed artifact, system or process should process" [17] (p. 236). Between the top level of values and the bottom level of design requirements, there is a mid-level of norms [17] 
(p. 240). Norms could include a state-of-affairs (e.g., residential satisfaction), a capability (e.g., being able to access to all locations in a house), an activity (e.g., to move safely in a neighborhood), or an objective (e.g., maximize health and safety in neighborhoods). However, in our definition, norms do not include specific targets to be achieved; such as those specific targets for which we design called design requirements (e.g., a minimum of three bedrooms is required for the building). Thus, our definition of norms is somewhat different than the use of the term in the policy discourse, where quantitative policy objectives, for example with regard to $\mathrm{CO} 2$ emissions, are also termed norms ( $\mathrm{CO} 2$ emissions norms). However, in our terminology, these are design requirements, because they relate to the more specific level of actually designing.

A few additional remarks seem to be in place before we move to discussing the relevance of values in housing policy. First, following Van de Poel, we believe that values, norms and design requirements have-in principle-a non-deductive relationship [17]. That is, norms cannot be logically deduced from values, and design requirements cannot be logically deduced from norms. Instead, the process of specification or operationalization of values is very contextual and depends very much on the case concerned. The relation between the levels has been described by Van de Poel [17], as one of "for the sake of", so that a norm is presented for the sake of the higher-level value. Second, and on a related note, it is very likely that within each context and case, more than one norm could be found for the sake of one value. Likewise, for the sake of a specific norm, several design criteria could be formulated. This also means that one norm could be presented for the sake of different values. Third, we argue that the top level of value could have sublayers. That is, some values can be abstract to the extent that they need to first be specified into other values before they can be used for design purposes; we call these 'meta values' inherent values. This specification within the layer of values could be helpful in the process of value specification; the values for the sake of 'inherent values' are called 'operational values' in this paper. Fourth, the literature on both DfV and VSD often refers to value conflicts or situations in which two values cannot be simultaneously accomplished. This can happen because different stakeholders uphold different incompatible values but also because different stakeholders assign a different meaning to the same value. The latter will be visible in the process of specification and is often expressed at the level of norms [18]. Fifth, a key normative question following value operationalization is how trade-offs are being made. There are different methods for dealing with conflicting values in design, for instance by comparing them with each other and assessing their relevance in relative terms $[19,20]$.

Why is the DfV Approach Unique and Indispensable?

We assert that a fine-grained analysis that could account for the plurality of values in housing is needed. This begs the question of whether this plurality cannot be offered by other approaches that also take into account a number of criteria. An important method in this regard is the Multi-Criteria Decision-Making (MCDM) method. MDCM is often used as an appraisal method for informing complex decisions in the field of transportation, logistics, and planning. MCDM has often been contrasted with aggregative (mostly economically driven) approaches that aim to maximize economic values. A prominent aggregative method in public policy is the Cost-Benefit Analysis (CBA) that aims to maximize utility in any decision. MCDM, as "a class of decision-making methods based on which a number of alternatives are evaluated with respect to a number of criteria", offers an alternative to inform and evaluate a decision based on several criteria [21] (p. 789). Thus, the MCDM method uses several criteria (as opposed to the single criterion of the CBA) for evaluation, and it is particularly suitable for situations whose complexity cannot be reduced to a single unit. Then, the choice is made by assigning weight to each criterion, which results in an 'aggregate' outcome. Meanwhile, MCDM helps us to take several criteria into account in a complex situation. The MDCM method is essentially an aggregate method, and it assumes that criteria can be expressed in a common standard or measurement and traded off against each other. For moral values, such an approach is problematic and quickly runs into methodological problems of commensurability [19]. However, a DfV approach does not result in a quantification or trade-off of values. Rather, it identifies and discusses the values at stake, while 
considering potential conflicting values. Moreover, and on a more practical note, the criteria used in MCDM are not necessarily moral values, whereas the DfV approach offers a vehicle to understand housing policy in terms of moral values at stake, while considering potentially conflicting values. This offers a genuine and valuable lens for the analysis.

\section{The Relevance of Values in Housing Policy}

In the housing and real estate studies, there is limited literature on the values of the decision-making professionals in the field of housing. However, the process of contribution to sustainability is a challenge for investors in real estate, and so the work on developing decision support systems is inspiring here. These earlier contributions unravel the concept of sustainability in different aspects [22] and provide an assessment of investment decisions and the role of environmental and social attributes [23]. The authors of this paper wish to add to this body of literature by bringing in the perspective of moral values that play a role in the housing policy and design debate.

The concept and right to "adequate" housing was already recognized in the 1948 Universal Declaration of Human Rights (article 25) and in the 1966 International Covenant on Economic, Social and Cultural Rights. Housing is closely related to well-being, since a lack of affordable housing "undermines individual health, wealth, and economic progress". Housing insecurity has negative psychological impacts [24], while improved housing conditions have favorable effects on education, health, and well-being [25]. Thus, adequate housing is considered a basic need for people.

More recently, there is recognition that the world is urbanizing rapidly, implying a huge need for housing in the cities. This makes the right to adequate housing a huge challenge for households, housing providers, and policy-makers. Therefore "Housing at the Centre of the Urban Agenda" was one of the conclusions of the Habitat III conference in Quito in 2016 [26]. Housing is of key importance for sustainable cities and communities, as indicated in Sustainable Development Goal 11.

The above paragraphs make it clear that housing is related to well-being and urban development, but housing also has an economic dimension: the residential real estate function. For most households, housing is the largest capital asset in their personal asset portfolio. Moreover, housing generates $10 \%$ of global gross domestic product (GDP) and 7\% of jobs worldwide and therefore is a substantial part of economies [27].

Dealing with these multiple dimensions of housing raises awareness that it is in reality a very political topic, as is demonstrated in discussions in parliaments across the world. Yet, solutions for adequate housing are closely linked to political ideals such as autonomy and (ontological) security. These ideals go hand-in-hand with political reflexes on, for example, policies for social housing or home ownership. By reflexes, we mean, for example, the immediate negative attitude of neo-liberals toward any discussion on public housing as well as the rejection of homeownership ideology among some left-wing politicians.

We think a discussion on values can feed the political debate by moving the focus from reflexes in debates to underlying values such as inclusiveness and sustainability that are shared or not. Housing is part of changing societies in which policies and values are changing and can be in conflict. Consequently, we argue here that exploring and explicating the underlying values of contemporary housing through these debates can create a better understanding of the current (lack of) fundamental discussions on housing issues. Moreover, identifying possible conflicts in values and norms at an early stage can improve future policy-making.

Currently, ideals for sustainable societies in the Urban Agenda go hand-in-hand with city boards inviting foreign investors to earn money in their cities, thereby pushing up house prices. So, the residential real estate is a home for people on the one side and a money machine for cities at the other side. Housing is an important source of income for many stakeholders: for the building industry, for developers, for investors, and also for municipalities and social housing providers. This implies that many organizations and people benefit from housing price increases as a result of housing scarcity. Yet, 
the urban dimension and the values underpinning the built environment and housing are not on top of the housing debate.

The several dimensions of housing make the housing debate complex, in particular, because the underlying values often remain implicit. Unravelling these values and identifying where and how they are in conflict can help to explain why policies on the ground are at odds with for example the aims for sustainable urban development as agreed in Quito at Habitat III.

\section{A Tentative List of Relevant Values for Housing Policy}

\subsection{Toward a Hierarchy of Values for the Housing Field}

In value research, often dozens of different values are discerned. To some extent, all these values will be relevant for the field of housing. After all, housing is a basic necessity, and it plays an important part in the life of individual people as well as within society as a whole. However, some values are clearly more important for housing than others. Table 1 provides an overview of the values that we consider as particularly relevant for the field of housing. This table is based on the Design for Values Approach in which a hierarchy of values can be discerned $[18,28]$ (see also Section 2 of this paper). We distinguish four different levels in our hierarchy: inherent values, operational values, norms, and design requirements. These are explained in the next paragraphs.

The inherent values have a value in their own right and have the potential to serve as guiding principles for policy-makers and individuals. Yet, these values are so abstract that it impossible to directly design dwellings or policies based on them.

The operational values are values that contribute to the accomplishment of the inherent values. Some operational values are conceptually quite close to the inherent values, while others are more specific and instrumental (this means that they can be seen as instrumental values, which was a concept introduced by Rokeach in 1973) [29]. The operational values often constitute a bridge between the inherent values on the one hand and the norms and design requirements on the other. For example, an inclusive neighborhood is only possible if dwellings are affordable and basic rules of procedural justice are respected.

While the Value Hierarchy aims at translating values into norms and then design requirements, one might argue that some inherent values are so abstract that an in-between level might be needed. That is one reason why we have decided to add operational values. It should be noted that some operational values are related to more than one inherent value. This alludes to the fact that the inherent values are also interconnected. For example, inclusiveness, ontological security, and autonomy are all expected to contribute to the well-being of individuals. To be sure, we do not claim that our presented set of values, as well as the proposed hierarchy between them, is ubiquitous. It merely serves as input for the discussion on values that we want to provoke.

Following the Value Hierarchy notion, we see norms as goals that specify a tangible target and/or constraints that set boundaries or minimum conditions. As mentioned in Section 2, they could include a state-of-affairs (e.g., residential satisfaction), a capability (e.g., being able to access to all locations in a house), an activity (e.g., to move safely in a neighborhood), or an objective (e.g., maximize health and safety in neighborhoods). The norms that are formulated in Table 1 merely serve as examples. As has been indicated in Section 2, the translation from values to norms can take place in various ways and is dependent on the context and the policy purposes.

Whereas the importance of the inherent values and the operational values will probably be accepted by most of the stakeholders of housing, discussions and conflicting opinions will start to arise once the values are translated into norms. Then, it will turn out that at this level, values may be in conflict with each other. For example, norms with regard to the energy performance of dwellings (arising from the inherent value sustainability and operational value ecological sustainability) may force people to invest in the adaptation of their house (in the case of owner-occupation), or may result in higher rents (in the case of rental dwellings). As a consequence of this, such norms may negatively 
affect the housing affordability (operational value) and the inclusiveness (inherent value) of housing markets and neighborhoods. In other words, there is a potential conflict between the inherent values of 'sustainability' and 'inclusiveness' that will only be visible when we translate these inherent values into other-more suitable for policy and design—operational values.

At the lowest level in the value hierarchy are the design requirements. In the case of housing, these requirements can refer to the design of dwellings (houses) but also to the design of housing policies. Norms can be translated into quantifiable design requirements in many ways. For instance, $\mathrm{CO} 2$ neutral dwellings can be achieved by insulation, but also by the generation of green energy, for example by placing solar panels on the roof. In a similar vein, affordable housing costs can be achieved by a myriad of policy interventions, ranging from housing allowances to rent regulation and from social housing allocation rules to the provision of cheap building land. The translation from norms into design requirements falls beyond the scope of this paper.

\subsection{A Further Specification of the Housing Value Hierarchy}

In this section, we will further underpin the relevance for housing of the values that we have selected. As a first step, we have provided a definition for each inherent value and operational value that we have discerned. These definitions can be found in the endnote part. Defining the values was not an easy task, since different academic disciplines apply different perspectives. In an attempt to build a bridge between the different academic disciplines that study housing, we have explicitly sought for rather short value working definitions that are hopefully shared by different disciplines.

After the values were defined, we have indicated why and how they play a role in the field of housing. How do the different values come back in housing practices and housing policy? Into what kind of norms can they be translated? Conciseness and generality are also key here, as it is impossible to be comprehensive. After all, each value is rooted in an extensive body of literature that cannot be summarized in one single paper. The main connections between the selected inherent and operational values and the domain of housing are also described in the endnote part.

In Table 1, seven inherent values have been selected: (ontological) security, autonomy, well-being, inclusiveness, sustainability, social stability, and market efficiency. There will probably be little controversy about the importance of these values for housing stakeholders. They play an important role in policy discourses about housing. Indeed, most housing stakeholders would agree that a well-experienced good housing design and a well-established good housing policy should be in line with the accomplishment of the seven values mentioned.

The first three inherent values in Table 1 mainly refer to the individual level. They are accomplished in interaction between the dwelling practices of individuals and households on the one hand and the built environment (this can refer to the dwelling but also to the neighborhood) on the other. The inherent value 'inclusiveness' can refer to both the individual level (accessibility in the dwellings) and the level of the community (inclusive neighborhoods), whereas the inherent values 'sustainability' and 'social stability' mostly refer to the level of the community. Finally, the value 'market efficiency' is about the organization of the community, with market allocation generally being perceived as the most efficient allocation mechanism. While one might legitimately ask whether market efficiency should be conceived at the level of inherent values, we choose to do so because a lot of housing literature seems to pinpoint that market efficiency is the key value for which policy is presented.

Table 1. Values, operational values, and norms that are particularly relevant for the field of housing.

\begin{tabular}{cccc}
\hline Inherent Values & $\begin{array}{c}\text { Operational Values } \\
\text { (Examples) }\end{array}$ & Norms (Examples) & Level \\
\hline Ontological security ${ }^{\mathrm{i}}$ & $\begin{array}{c}\text { Physical and social safety, } \\
\text { affordability }\end{array}$ & $\begin{array}{c}\text { Low chance of becoming victim of } \\
\text { crime, safe dwellings, affordable } \\
\text { housing costs, rent regulation, and } \\
\text { tenant security }\end{array}$ & Individual \\
\hline
\end{tabular}


Table 1. Cont.

\begin{tabular}{|c|c|c|c|}
\hline Inherent Values & $\begin{array}{l}\text { Operational Values } \\
\text { (Examples) }\end{array}$ & Norms (Examples) & Level \\
\hline Autonomy ${ }^{\mathrm{ii}}$ & $\begin{array}{l}\text { Freedom of choice, autarky, } \\
\text { privacy, home-making iii }\end{array}$ & $\begin{array}{l}\text { Sufficient space within the } \\
\text { dwelling, subjective sense of } \\
\text { feeling at home, housing } \\
\text { satisfaction, degree of self- } \\
\text { sufficiency }\end{array}$ & Individual \\
\hline Well-being iv & $\begin{array}{l}\text { Physical and social safety, } \\
\text { health, accessibility, social } \\
\text { cohesion }\end{array}$ & $\begin{array}{l}\text { Low chance of becoming victim of } \\
\text { crime, safe dwellings, accessible } \\
\text { dwellings, life satisfaction, housing } \\
\text { satisfaction, neighborhood } \\
\text { satisfaction, quantity and quality of } \\
\text { local social contacts }\end{array}$ & Individual \\
\hline Inclusiveness ${ }^{\mathrm{v}}$ & $\begin{array}{l}\text { Accessibility, affordability, } \\
\text { procedural justice vi }^{\text {vi }}\end{array}$ & $\begin{array}{c}\text { Accessible dwellings, affordable } \\
\text { housing costs, transparency in } \\
\text { procedures }\end{array}$ & $\begin{array}{l}\text { Individual } \\
\text { and } \\
\text { community }\end{array}$ \\
\hline Sustainability vii & $\begin{array}{l}\text { Ecological sustainability, } \\
\text { social sustainability, } \\
\text { economic sustainability, } \\
\text { resilience, viii circularity, } \\
\text { durability, adaptability, }\end{array}$ & $\begin{array}{l}\text { Energy-efficient dwellings, } \\
\text { CO2-neutral dwellings, reusable } \\
\text { building materials, voluntary } \\
\text { certification systems, degree of } \\
\text { self-governance }\end{array}$ & Community \\
\hline $\begin{array}{l}\text { Social stability/order } \\
\text { (local community }^{\text {level) }}{ }^{\text {ix }}\end{array}$ & $\begin{array}{c}\text { Sense of community, }{ }^{\mathrm{x}} \text { social } \\
\text { cohesion, social safety, } \\
\text { vernacular, place making }\end{array}$ & $\begin{array}{l}\text { Neighborhood satisfaction, social } \\
\text { interaction, appreciation of the } \\
\text { neighborhood, perceived identity } \\
\text { of the neighborhood, community } \\
\text { forming }\end{array}$ & Community \\
\hline Market efficiency xi & $\begin{array}{c}\text { Economies of scale, } \\
\text { optimization of procedures, } \\
\text { market as optimal allocation } \\
\text { mechanism }\end{array}$ & $\begin{array}{l}\text { Maximum delivery of products or } \\
\text { services against minimal costs, } \\
\text { reduce government involvement }\end{array}$ & Community \\
\hline \multicolumn{4}{|c|}{ 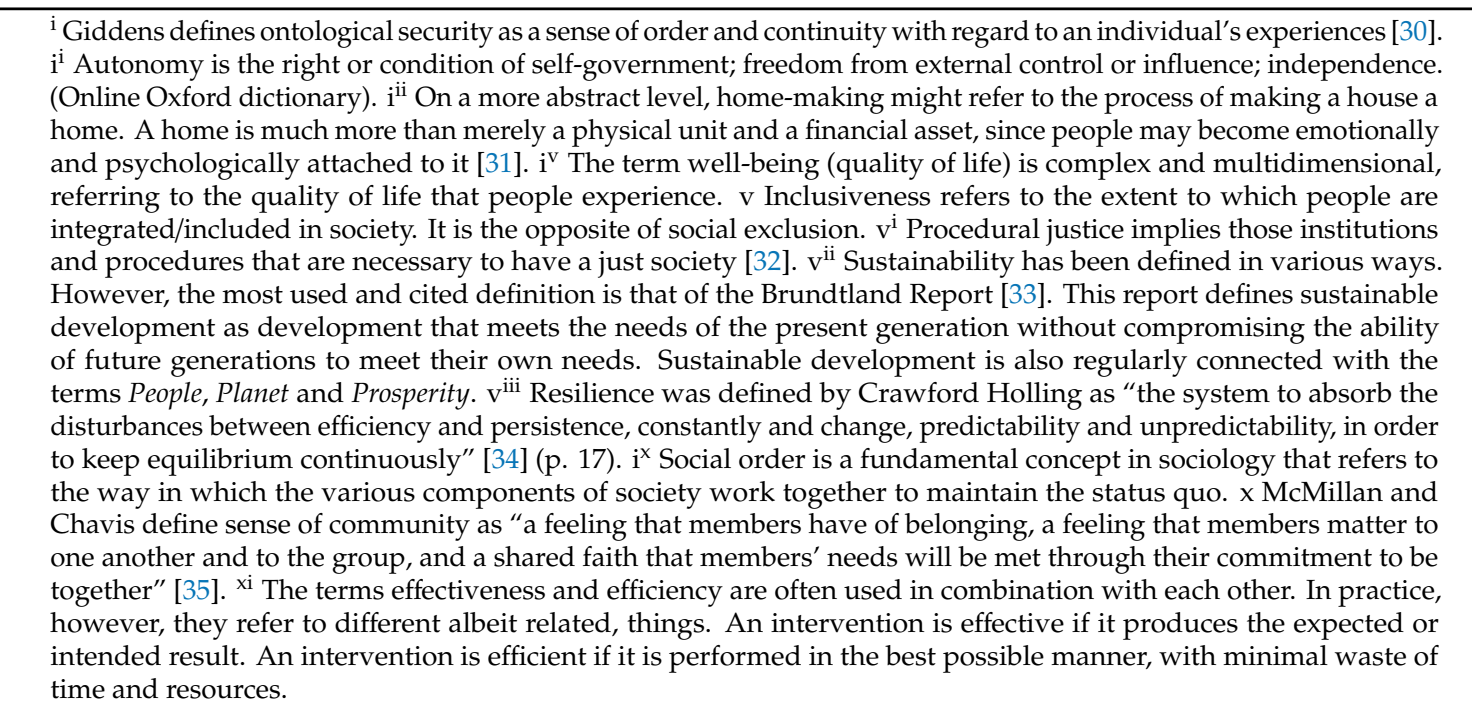 } \\
\hline
\end{tabular}

\section{Debates in Housing and the Role of Values}

Architects and urban planners/designers are taught to design the built environment in order to support ideals in society. These ideals can be part of movements that go far beyond the built environment such as modernization. Designs, and the ideals behind design, went hand in hand with policies and institutions to make housing affordable, such as subsidies and non-profit organizations providing affordable housing. This section explores debates, movements, and ideals in housing and tries to link these to underlying values and norms as they are described in the previous section. 


\subsection{Ideals for Design of Housing and Urban Communities}

The modernization movement was much broader than the aspects of housing and urbanization that started at the end of the $19^{\text {th }}$ century. 'Modernization theory' viewed development as a predominantly linear process of economic and social change occurring as societies moved from being rural, traditional, small-scale, and familial systems to develop more complex, corporate, and international levels of economic activity and labor organization. This was accompanied by an acceleration in the rate of urbanization and resulted in changes in value systems largely oriented toward consumerism, and based upon broader associational criteria and networks (in contrast to familial systems). The emphasis was on cultural rather than class-based values, with social change involving a fundamental recasting of those values from traditional to more modern ways of thinking and more modern (i.e., urban) patterns of behavior [36].

As urbanization continued in the Western world, planners were occupied with planning cities and housing for modern people: high rise and division of functions (the so-called functional city). Housing modernization first reached a peak in the 1950s and 1960s in the West, and then in the late 1960s and the 1970s in many non-Western countries, playing a key role in responding to the urgent housing needs arising after the Second World War. These ideas about modern societies went hand in hand with a strong belief in governments as architects of society. This resulted in huge housing projects designed by believers in modernism, such as le Corbusier, across the world. A well-known example was Pruitt Igoe: a public housing project designed in Saint Louis (US) in the 1950s as an advanced housing solution for people living in slums. Housing was regarded as a means of emancipation, and the creation of modern communities was envisaged through brick and mortar construction. The Pruitt Igoe project was presented as a very successful project, but it ended in complete demolition after 16 years. There is a variety of explanations for this, of which the first was the shrinkage of St. Louis, implying that middle-income groups left the city, and only the most vulnerable groups stayed in Pruitt Igoe. Moreover, a lot of thinking was spent on the building, but little was spent on the period after finishing the building, and there were no budget reservations for the subsequent management and maintenance of the buildings. Finally, the high-rise buildings did not meet the preferences of many households: the need for defensible spaces and community living [37]. This example shows that an inadequacy in design for values, or an unawareness of the broader set of values that need to be included in design, could result in the failure of a project. A comparable Dutch example is the Bijlmer that was built in the 1960s in the Netherlands. This ideal part of the city appeared a problem area already in the 1980s and was therefore partly demolished and partly renovated. The huge costs of these failed ideals forced reconsidering ideas of modernization in housing policies.

This resulted in a fundamental change in the way the right to housing is addressed in particular in the so-called 'urban global South' (developing countries): from top-down presentation of an ideal to providing public services and relying on the skills and responsibility of people. In the late 1960s and early 1970s, architects and planners began to advocate for state assistance in the form of basic service infrastructure, improved road access and, in some cases, formal titles for existing irregular settlements. Such policies were adopted as state interventions aimed at providing 'elements' that could not easily be provided by the populations themselves (e.g., water, drainage, power, street paving, and access), while leaving housing construction and home consolidation to the residents themselves [38]. Turner refers to this as "housing that works" [39]. Although these ideas emerged from research conducted since the late 1960s, they did not begin to take hold until the World Bank started to promote them in the early 1970s and especially in 1976, following the first United Nations (UN) Habitat conference in Vancouver and the creation of a UN Habitat Center in Nairobi [36]. This fundamental change about affordable housing for vulnerable groups demonstrates a change in the role of government and individual households in building and maintaining homes. This seems to refer to a change in dominant values about creating social stability and autonomy of the vulnerable households. 


\subsection{Neo-liberalization: Focus on Market Efficiency}

The global spread of neo-liberalism since the 1990s has had a major impact on housing policies. One key assumption of neo-liberalist thought is that people are rational and competition is efficient. The highest utility for society could be achieved by allowing maximum room for demand and supply, thereby arriving at optimal pricing. However, this optimal outcome requires that markets are perfect or, in other words, they do not suffer from market inefficiencies such as a lack of transparency, unequal market power, or externalities. Government-led policies can compensate for such market inefficiencies and in that way support optimal welfare. Since the 1990s, 'market efficiency' thinking has dominated the conversation on housing across the world. This type of thinking focuses on the market as the most efficient allocation mechanism, thus leading to the dominance of policies that support the market allocation: the privatization of public housing, deregulation of prices, and reduction of subsidies. The goal of 'making housing work' was replaced by the goal of 'making housing markets work'. In other words, the focus shifted to reconsidering housing arrangements that disturb markets. Whereas informal housing was often considered a solution for affordable housing in the Global South, in 'market efficiency' thinking, informal housing is inefficient, and there are only two solutions to solve this problem: 'demolish or formalize'. Housing policies as part of Western welfare states became part of 'market efficiency' thinking: market allocation is the most efficient and therefore produces the maximum housing outcomes for societies.

This worldwide dominant market efficiency thinking had a huge impact on housing policies:

Changing subsidy mechanisms: Market efficiency is a key issue in neo-liberal thinking; in housing, this resulted in the idea that it is more efficient to subsidize people than to subsidize houses. If you subsidize people, you can adapt the amount of subsidies easily when the income of the people changes. If you subsidize houses, it is complex to change the price of the house when the income of the owner or tenant changes. Housing allowances given directly to the households were considered more efficient than subsidizing dwellings [40]. In the 1980s and 1990s, a transition from "brick-and-mortar" subsidies for houses to income-dependent housing allowances for households took place many West European countries. At the same time, there was a huge World Bank program for affordable housing in Latin America based on the same principle. This so-called enabling policy is also based on the idea that it is most efficient to provide money directly to the households. The Minha Casa Minha Vida program for low-income homeownership in Brazil is a typical example of this approach.

Strong support for home ownership as owner-occupied housing is considered typical market efficient housing. The deregulation of financial markets is an expression of the neoliberal mission. This resulted in easier access to mortgages that went hand-in-hand with policies to encourage home ownership. Innovations in the mortgage market made homeownership more accessible. Interest-only mortgages, subprime loans, and similar products reduced initial expenses to lower levels and made mortgage loans accessible to groups who had previously been excluded [41].

Support private renting: A reduction of social housing is accompanied by support for the private rental sector. One important question for housing policy officers is how to make the commercial rental market appealing to investors. For example, the United Kingdom's 'buy to let' arrangement (purchase to rent) is intended to attract people to invest in private rental housing. Somewhat similar private rental sector policies, but with more focus on affordability, were developed in Germany and France [42].

Marketizing social housing: The market efficiency thinking assumes that market allocation produces the most efficient outcomes and that governments can compensate for market failures. Non-profit provision is considered inefficient and thus not desired [43]. Therefore, social housing provision is criticized as inefficient, in particular social housing providers that provide to middle income groups. In countries with substantial social rental sectors, "privatization" involves pushing rents up to market prices and attracting private capital to social housing. This was particularly fueled by the discussion within the European Union (EU) concerning state aid and false competition. One consequence was that social housing providers had to start operating as private-sector companies, particularly in Sweden, the Netherlands, and the United Kingdom. At the same time, social housing providers were forced to 
target only lower-income households [44]. This implied the end of a "broad social rental sector" as a key policy in welfare states and urban design. This broad social rental sector was associated with the value inclusiveness.

Neo-liberal thinking included a move away from thinking about what dwellings and neighborhoods should look like, toward the efficiency of policies to make housing affordable. Even within the field of the social housing market, efficiency thinking became dominant; there was a focus on market rents, market value, and efficient allocation [45]. In this debate, 'market efficiency' appeared to be the driving inherent value.

\subsection{Current Debates in Dutch Housing}

The Netherlands has a long tradition in debating adequate housing and solutions to address this societal issue. The Dutch solution of a broad social rental sector run by private not-for-profit housing associations appeared inspiring to many other countries in the world. Therefore, the current debate on affordable housing in the Netherlands is an interesting one.

\subsubsection{Rethinking Dutch Social Housing}

The prices of social housing are "below market prices"; thus, they are too low according to market efficiency principles, and therefore, the Dutch government introduced a landlord tax for affordable housing. Landlords owning dwellings with a monthly rent below $€ 711$ have to pay a tax per dwelling. At the same time, for many tenants, the rent is rather high: a substantial amount of households living in social housing experience affordability problems according to Dutch affordability standards [46]. This raises the question: how social is social housing? Remarkably, the conclusion of the Spatial Planning Bureau is that high housing costs should be considered an income problem and not a housing affordability problem: people have an income lower than the social minimum norm. There appears to be no coherence between social and housing policies in the changing welfare state. What are the underlying values here; how is social housing linked to inclusiveness and sustainability?

In a new climate agreement, the government is forcing housing associations to act as a role model in making the housing stock energy-neutral. However, practice demonstrates that investments to make dwellings energy-neutral are far behind the ambitions of social housing associations and the objectives set by the central government [47]. The ambition to make houses energy-neutral appears to conflict with keeping or making houses affordable for low-income households. This demonstrates the lack of a clear vision by the national government on the role of housing associations: they have to pay a high tax, keep the rents affordable, and at the same time housing associations have to invest to make their stock energy-neutral. In this case, the underlying values of inclusiveness and sustainability are conflicting when it comes to the operational values and design requirements for policies.

\subsubsection{Away from National Policies}

There is an emerging idea that governments are no longer responsible for housing solutions. Instead, there is more and more emphasis on solutions from society: big society, participation society, or social innovations are considered alternative responses to the failures of the market and the withdrawal of the government. Community-led housing is a new trend in many places, and the sense of community is a value that is a strong driver for this kind of housing provision [48]. Cooperatives, community-land trusts, and similar initiatives can keep housing affordable, given that they are non-profit organizations. This idea is also present in the Dutch debate on affordable housing. However, there is a great deal of evidence that such initiatives often struggle with existing regulations, difficulty in attracting finance, and overcoming the lack of professional knowledge. It appears that big society is a concept promoting the inherent value social stability and the operational value sense of community. However, the requirements for design do not match with existing regulations that were guided by other values. Again, here we observe a conflict of values that becomes visible in the requirements for policy design. 


\subsubsection{What is "Adequate" Housing?}

The Netherlands has a long tradition of housing policies to support an increase of housing quality. The average amount of square meters of living space per person increased from $8 \mathrm{~m}^{2}$ in 1900 to $55 \mathrm{~m}^{2}$ per person in 2018 [49]. This increase was strongly supported by subsidies. The high quality of social housing is no longer supported by subsidies from the central government; instead, it translated into high prices that are not affordable for many. The need for affordable housing results not only in long waiting lists but also in people living in "unaffordable" social housing. There seems to be a mismatch between the inherent value inclusiveness, the operational value affordability, and the design requirement: housing expenses in relation to income.

At the same time, new solutions are emerging in the private rental sector to satisfy the huge need for affordable housing: rooms, flexible housing, container housing, micro housing, and tiny housing. These are the only options that are affordable for many, but the question is whether this is adequate housing? This question is not on the political agenda nor a question of whether there are minimal criteria for quality relating to the value well-being. There is debate about the increase of "rooming": splitting houses into rooms, each one for a different tenant. The question is whether this is considered adequate housing. Is rooming and sharing a front door and several facilities a solution for affordable housing, or is it a problem threatening livability in cities? This requests a fundamental discussion about underlying values such as ontological security, autonomy, and well-being.

The answer of the current Dutch national government to the current problems in the housing market is to encourage the private rental market and to promote the ambition to build 1 million homes before 2030. This 1 million homes ambition is a call of the minister for housing that is up to now not supported by any policies. "Big society" is supposed to find the solution. This requires rethinking the current system and the institutions involved in housing provision.

\section{Reflection}

This article is a joint effort of a philosopher, an architect, and two housing study experts. The aim is to apply the philosophical approach of Design for Values to the field of housing. Our conclusion is that it has been an adventurous and rewarding journey. We think that bringing in the Design for Values approach can help the debate on affordable and sustainable housing. The debate on affordable housing and housing crises is full of strong political opinions, but the underlying values often remain implicit.

The authors recognize that there have been tempting ideologies in the field of housing and urban planning to improve the world. These ideologies were translated into solutions, and some failed at the cost of billions of whatever currency. Some lessons are hopefully learned, but the term "housing crises" is used often over time and in many poor as well as rich countries. The approach of using a framework of values may help to bridge the gap between high-level ideologies about housing and the housing problems in practice.

Why is the lack of (affordable) housing so much in the news? It is because housing is a human right, it is a way to create inclusive societies and sustainable cities, and at the same time, it is a money-maker and a crucial part of our economy. What are underlying the values, operational values, norms, and design requirements in this debate? We think the perspective of moral values can support the debate on affordable housing. For the latter purpose, we have tried to shed light on these implicit values by presenting a tentative list of values that have historically played an important role in the housing debate (see Table 1). At the same time, we acknowledge that the validity and applicability of this hierarchical housing value list needs to be the subject of further research.

We conclude that the values of sustainability and inclusiveness are nowadays key issues in housing and urban development. However, both of these are hardly operationalized, and as a result of this, it remains unclear what they mean in practice. Moreover, the values 'sustainability' and 'inclusiveness' may be in conflict with each other, such as for example when sustainability requirements result in higher housing costs. The DfV approach allows for a systematic unraveling of values into norms and design requirements, thereby signaling potential value conflicts. Our hypothesis is that such an 
approach can pave the way toward sound housing solutions. Therefore, applying the DfV approach to the topic of sustainable and inclusive housing and translating the relevant values into norms and design requirements is a challenging next research step.

Author Contributions: M.E. is an expert in housing and wrote the part on the ongoing value related debate on housing in the Netherlands. J.H. is an expert in housing policy and M.S. is an expert in housing design, together they wrote the part on values that play a role in housing policy and design. B.T. is an expert in ethics for design and wrote the part on Design for Values. The fruitful discussion within this team of authors resulted in this article. All authors have read and agreed to the published version of the manuscript.

Funding: This research was funded by the Delft Design for Values Institute: https://www.delftdesignforvalues.nl/.

Acknowledgments: An earlier drafts of this paper has been presented at the Values and Housing Workshop that was organized at Delft University of Technology in March 2019. In addition to thanking the audience of this workshop, the authors wish to thank the anonymous reviewers for their useful comments. The authors would also like to acknowledge the editing by Paul W. Fox of an earlier draft of this paper.

Conflicts of Interest: The authors declare no conflict of interest.

\section{References}

1. Turner, J.F. Housing as a verb. Freedom Build 1972, 148-175.

2. Friedman, B.; Kahn, P.H., Jr. New directions: A value-sensitive design approach to augmented reality. In Proceedings of the DARE 2000 on Designing Augmented Reality Environments, Elsinore, Denmark, 12-14 April 2000; pp. 163-164.

3. Van Den Hoven, J. ICT and value sensitive design. In The Information Society: Innovation, Legitimacy, Ethics and Democracy in Honor of Professor Jacques Berleur SJ; Goujon, P., Lavelle, S., Duquenoy, P., Kimppa, K., Laurent, V., Eds.; Springer: Berlin/Heidelberg, Germany, 2007; pp. 67-72.

4. Nissenbaum, H. Values in technical design. In Encyclopedia of Science, Technology, and Ethics; Mitcham, C., Ed.; MacMillan: New York, NY, USA, 2005; pp. 66-70.

5. Van De Poel, I. Values in engineering design. In Philosophy of Technology and Engineering Sciences; Meijer, A., Ed.; Elsevier: Amsterdam, The Netherlands, 2009; pp. 973-1006.

6. Van Den Hoven, J.; Vermaas, P.E.; Van De Poel, I. (Eds.) Handbook of Ethics and Values in Technological Design: Sources, Theory, Values and Application Domains; Springer: Berlin/Heidelberg, Germany, 2015.

7. Taebi, B.; Kloosterman, J.L. Design for values in nuclear technology. In Handbook of Ethics, Values, and Technological Design: Sources, Theory, Values and Application Domains; Van den Hoven, J., Vermaas, P., Van de Poel, I., Eds.; Springer: Berlin/Heidelberg, Germany, 2015; pp. 805-829.

8. Friedman, B.; Hendry, D. Value Sensitive Design: Shaping Technology with Moral Imagination; The MIT Press: Cambridge, MA, USA, 2019.

9. Friedman, B. Value-sensitive design. Interactions 1996, 3, 16-23. [CrossRef]

10. Friedman, B.; Kahn, P.; Borning, A. Value Sensitive Design: Theory and Methods. University of Washington Technical Report. 2002. Available online: https:/faculty.washington.edu/pkahn/articles/vsd-theory-methodstr.pdf (accessed on 1 October 2019).

11. Van Den Hoven, J.; Vermaas, P.E.; Van De Poel, I. Design for Values: An Introduction. In Handbook of Ethics, Values, and Technological Design: Sources, Theory, Values and Application Domains; Van Den Hoven, J., Vermaas, P.E., Van De Poel, I., Eds.; Springer: Berlin/Heidelberg, Germany, 2015; pp. 1-6.

12. Churchill, W. We shape our buildings, and afterwards our buildings shape us. Available online: https: //www.parliament.uk/about/living-heritage/building/palace/architecture/palacestructure/churchill/ (accessed on 1 October 2019).

13. Friedman, B.; Borning, A.; Huldtgren, A. Value Sensitive Design and Information Systems. In Human-Computer Interaction and Management Information Systems: Foundations; Zhang, P., Galletta, D.F., Eds.; M.E. Sharpe: Armonk, NY, USA, 2006.

14. Jørgensen, T.B.; Bozeman, B. Public values: An inventory. Adm. Soc. 2007, 39, 354-381. [CrossRef]

15. Norman, R. Ethics and the Market; Ashgate: Aldershot, Hants, UK, 1999.

16. Hausman, D.; McPherson, M.; Satz, D. Economic Analysis, Moral Philosophy, and Public Policy; University Press: Cambridge, UK, 2016. 
17. Van De Poel, I. Translating values into design requirements. In Philosophy and Engineering: Reflections on Practice, Principles and Process; Michelfelder, D.P., McCarthy, N., Goldberg, D.E., Eds.; Springer: Berlin/Heidelberg, Germany, 2014; pp. 253-266.

18. Dignum, M.; Correljé, A.; Cuppen, E.; Pesch, U.; Taebi, B. Contested Technologies and Design for Values: The Case of Shale Gas. Sci. Eng. Ethics 2016, 22, 1171-1191. [CrossRef] [PubMed]

19. Van De Poel, I. Conflicting values in design for values. In Handbook of Ethics, Values, and Technological Design: Sources, Theory, Values and Application Domains; Van Den Hoven, J., Vermaas, P., Van De Poel, I., Eds.; Springer: Berlin/Heidelberg, Germany, 2015; pp. 89-116.

20. Van De Kaa, G.; Rezaei, J.; Taebi, B.; Van De Poel, I.; Kizhakenath, A. How to Weigh Values in Value Sensitive Design: A Best Worst Method Approach for the Case of Smart Metering. Sci. Eng. Ethics 2020, 26, 475-494. [CrossRef] [PubMed]

21. Annema, J.A.; Mouter, N.; Razaei, J. Cost-benefit analysis (CBA), or multi-criteria decision-making (MCDM) or both: politicians' perspective in transport policy appraisal. Transp. Res. Procedia 2015, 10, 788-797. [CrossRef]

22. Saaty, T.L.; De Paola, P. Rethinking design and urban planning for the cities of the future. Buildings 2017, 7, 76. [CrossRef]

23. Del Giudice, V.; De Paola, P.; Francesca, T.; Nijkamp, P.J.; Shapira, A. Real estate investment choices and decision support systems. Sustainability 2019, 11, 3110. [CrossRef]

24. Bone, J. Neoliberal nomads: Housing insecurity and the revival of private renting in the UK. Sociol. Res. Online 2014, 19, 1-14. [CrossRef]

25. Arku, G. The housing and economic development debate revisited: Economic significance of housing in developing countries. J. Hous. Built Environ. 2006, 21, 377-395. [CrossRef]

26. UN-Habitat. Official Documentation. Available online: http://habitat3.org/the-conference/officialdocumentation/ (accessed on 1 October 2019).

27. UN-Habitat. Planning Sustainable Cities_Global Report on Human Settlements 2009. Available online: https://mirror.unhabitat.org/content.asp?typeid=19\&catid=555\&cid=5607 (accessed on 1 October 2019).

28. Correljé, A.; Cuppen, E.; Dignum, M.; Pesch, U.; Taebi, B. Responsible Innovation in Energy Projects: Values in the Design of Technologies, Institutions and Stakeholder Interactions. In Responsible Innovation 2: Concepts and Approaches; Koops, B.J., Oosterlaken, I., Romijn, H., Swierstra, T., Van Den Hoven, J., Eds.; Springer: Berlin/Heidelberg, Germany, 2015; pp. 183-200.

29. Rokeach, M. The Nature of Human Values; Free Press: New York, NY, USA, 1973.

30. Giddens, A. Modernity and Self-Identity: Self and Society in the Late Modern Age; Wiley: Hoboken, NJ, USA, 2013.

31. Marcus, C.C. House as a Mirror of Self: Exploring the Deeper Meaning of Home; Nicolas-Hays, Inc.: Newburyport, MA, USA, 2006.

32. Madanipour, A.; Schucksmith, M.; Talbot, H.; Crawford, J. Deliverable 1.1 Conceptual Framework for the Project, Report for the Relocal project; European Commission: Brussels, Belgium, 2017.

33. Brundtland, G.H. Report of the World Commission on Environment and Development: Our Common Future; World Commission on Environment and Development: Stockholm, Sweden, 1987; Published as Annex to General Assembly document A/42/427, development and international Co-operation: Environment August 1987, 2.

34. Holling, C.S. Resilience and Stability of Ecological Systems. Annu. Rev. Ecol. Syst. 1973, 4, 1-23. [CrossRef]

35. McMillan, D.W.; Chavis, D.M. Sense of community: A definition and theory. J. Community Psychol. 1986, 14, 6-23. [CrossRef]

36. Ward, P.M. Housing Policies in Developing Countries. In International Encyclopedia of Housing and Home; Smith, S., Elsinga, M., Fox-Mahony, L., Seow Eng, O., Wachter, S., Eds.; Elsevier Ltd: Oxford, UK, 2012; pp. 559-572. [CrossRef]

37. Heathcott, J. Planning note: Pruitt-igoe and the critique of public housing. J. Am. Plann. Assoc. 2012, 78, 450-451. [CrossRef]

38. Gilbert, A.; Ward, P.M. Housing, the State, and the Poor: Policy and Practice in Three Latin American Cities; Cambridge University Press: Cambridge, UK, 1985.

39. Turner, J.F.C.; Fichter, R. Freedom to Build; Dweller Control of the Housing Process; Macmillan: New York, NY, USA, 1972.

40. Kemp, P.A. Private renting in England. Neth. J. Hous. Environ. Res. 1998, 13, 233-253. [CrossRef] 
41. Schwartz, A.F. Housing Policy in the United States; Routledge: Abingdon, UK, 2014.

42. Whitehead, C.; Monk, S.; Scanlon, K.; Markkanen, S.; Tang, C. The Private Rented Sector in the New Century-A Comparative Approach; Boligokonimisk Videncenter: Copenhagen, Denmark, 2012.

43. Elsinga, M.; Lind, H. The Effect of EU-Legislation on Rental Systems in Sweden and the Netherlands. Hous. Stud. 2013, 28, 960. [CrossRef]

44. Haffner, M.; Hoekstra, J.; Oxley, M.; Van Der Heijden, H. Bridging the Gap between Social and Market Rented Housing in Six European Countries? I; IOS Press: Amsterdam, The Netherlands, 2009.

45. Conijn, J. Kennis is Als Een Fata Morgana. Hervorming Van De Woningmarkt: Resultaten En Lessen Voor De Toekomst-Afscheidsrede; University of Amsterdam: Amsterdam, The Netherlands, 2019.

46. Haffner, M.; Boumeester, H. Housing affordability in the Netherlands: The impact of rent and energy costs. J. Hous. Built Environ. 2015, 30, 293-312. [CrossRef]

47. Filippidou, F. Energy Performance Progress of the Dutch Non-Profit Housing Stock: A Longitudinal Assessment; TU Delft Open: Delft, The Netherlands, 2018.

48. Lang, R.; Carriou, C.; Czischke, D. Collaborative Housing Research (1990-2017): A Systematic Review and Thematic Analysis of the Field. Hous. Theory Soc. 2020, 37, 10-39. [CrossRef]

49. CBS. Woonoppervlakte in Nederland. Available online: https://www.cbs.nl/nl-nl/achtergrond/2018/22/ woonoppervlakte-in-nederland (accessed on 1 October 2019).

(C) 2020 by the authors. Licensee MDPI, Basel, Switzerland. This article is an open access article distributed under the terms and conditions of the Creative Commons Attribution (CC BY) license (http://creativecommons.org/licenses/by/4.0/). 